\title{
e-Government Village Model
}

\author{
Ronal Watrianthos ${ }^{1}$, Yudi Triyanto ${ }^{2}$, Pristiyono $^{3}$, Desmawaty Hasibuan $^{4}, \mathrm{Samsir}^{5}$ \\ \{ronal.watrianthos@gmail.com ${ }^{1}$, triyantoyudi81@gmail.com, paktio16@gmail.com\} \\ 1,2,3,4,5 Universitas Labuhan Batu, Rantauprapat, Indonesia
}

\begin{abstract}
E-Government development has become government commitment as established in the Inpres 3/2003 concerning the National E-Government Development Policy and Strategy. However, this government policy has not been fully implemented in local government, resulting in the e-Government role as the pledge of the government that cannot run well. Resistance to change is one of the inhibiting factors in eGovernment development. Law No. 6 of 2014 about Villages states that the implementation of village governance by utilizing Information Technology can be done through e-Government Villages. An in-depth study of models suitable for e-Government villages is needed. The process of identifying the Village e-Government needs is carried out with a Critical Success Factor (CSF) analysis. The results of the analysis produce four stages of the model which are divided into dimensions of technological complexity and organization with the level of data and information integration. Whereas the results of portfolio futures from the development of this model using McFarlan's Analyst Grid so that strategic modules, high potential, support, and operational key can be elaborated.
\end{abstract}

Keywords: E-Government, Village, Model, CSF

\section{Introduction}

The development of Information Technology is currently growing rapidly, especially in various sectors. The role of Information Technology has an impact on better support for information access and processing toward public services at the regional as well as the central level. The Indonesian government is considered to have less role in producing policies and actions in each sector by utilizing Information Technology in supporting the performance of public services (e-Government). In the E-Government Development Index (EGDI) issued by the United Nations for 2018, Indonesia is ranked 107th, far below Malaysia which is ranked 48th and Singapore in the 7th rank of the world[1].

The indicator of this index assessment is the role of e-Government in the dissemination of public information, access or ease of use of public information, and the capability of public services. Reflecting on Singapore, one of the keys to successful e-Government implementation is a mature information system strategic planning[2]. The initial foundation in the implementation of e-Government has been established in Inpres 3/2003 concerning National E-Government Development Policy and Strategy[3]. Other regulations at the national level besides the Presidential Instruction are Presidential Regulations concerning the implementation of e-Government in central and regional government agencies[4]. Based on the results of assistance and guidance during 2017, the state can save a budget of up to Rp. 41.15 trillion in 5 Ministries and Institutions, 7 Provincial Governments, and 113 District / City Governments[5]. 
Likewise, with the village government, the village as part of the lowest governance in the national government structure has the authority to regulate its territory (autonomous) within the framework of the Unitary State of the Republic of Indonesia[6]. Village Development, according to Law No. 6 of 2014 concerning Villages, is an effort to improve the quality of life and life for the greatest welfare of the village community[7]. So that village development can be sustained through the concept of e-Government for village government public sector organizations. Implementation of village governance by utilizing Information Technology makes e-Government Village a vehicle for accountability of village governments for governance, so that an independent, transparent and accountable government will be created. E-Government in village governance is not only a matter of a village website but is an integrated system of information technology that makes the village government more efficient and transparent as mandated by the Village Law. Information Technology Support in the village government will encourage single data that is always updatable through the village apparatus[8]. It is on this basis that this study intends to conduct a study of the development of e-Government models for local government at the village level as the basic foundation of public services at the above levels of government. E-Government Village Development is expected to be a strategic step in realizing community prosperity through an efficient and transparent village government management system of abolition by the Village Law. The development of the e-Government model at the local government level itself was formulated by Deepak Bhatia in 2012 through an information system and information technology strategic plan in a small town in Bharat India[9]. Strategy preparation begins with formulating a conceptual framework consisting of leadership dimensions, human resources, institutional reform policies, technology, and costs. Figure 1 shows the resulting output is Information Technology Management, Information Technology infrastructure development, and back end applications that can support government performance[10].

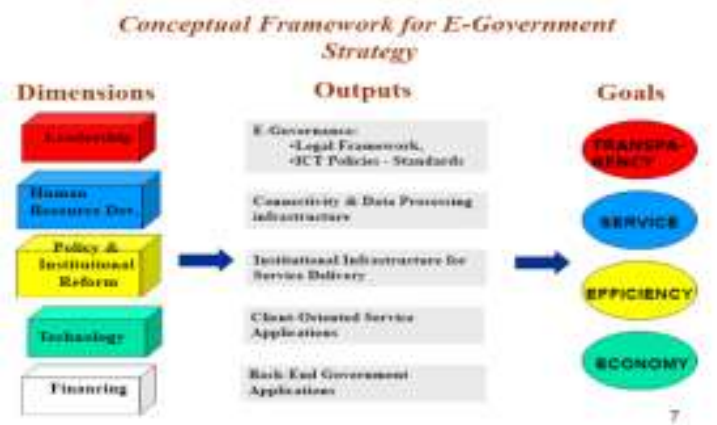

Fig. 1. E-Government Concept[10]

\section{Method}

\subsection{Identification of Village Scope}

At this stage, an identification process is carried out on the village scope including the formulation of literature on the village in terms of legal and legal aspects. It is also necessary to review the arrangements, principles, principles, and patterns of public service delivery[2]. Observations were carried out with several villages in Labuhanbatu District as sampling in this study. The information collection was also carried out through interviews and questionnaires 
on the needs of village officials related to their duties and functions in village public services. This identification process must refer to Law No. 6 of 2014[7]. In the process of identifying the scope of this village, it is necessary to consider whether the concept of e-Government supported by information systems in village development can be the main focus of the village government in planning and monitoring village development[9].

\subsection{Identification of Information and Communication Technology}

The identification process in the second and the first stages will be analyzed using the Critical Success Factors (CSF) analysis method. The purpose of this analysis is to interpret objects more clearly in determining what activities should be done and what information is needed[11]. In CSF, there are three paradigms in determining the success of e-Government development[12], namely the Organizational Paradigm, Technology Paradigm, and User Paradigm as described in Figure 2 below.

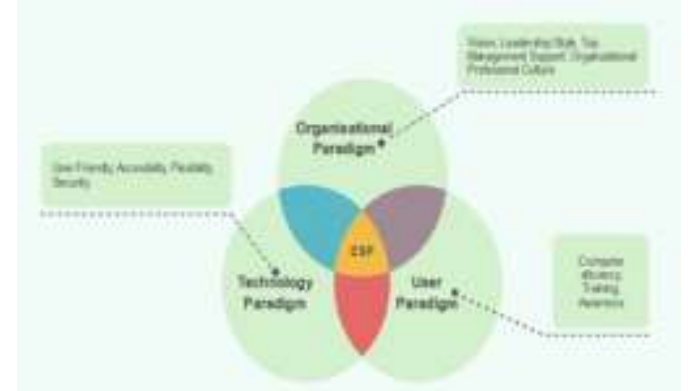

Fig. 2. Three Paradigms in determining the Success of e-Government[12]

The development of three paradigms in Figure. 3 is described in Figure 4 below.

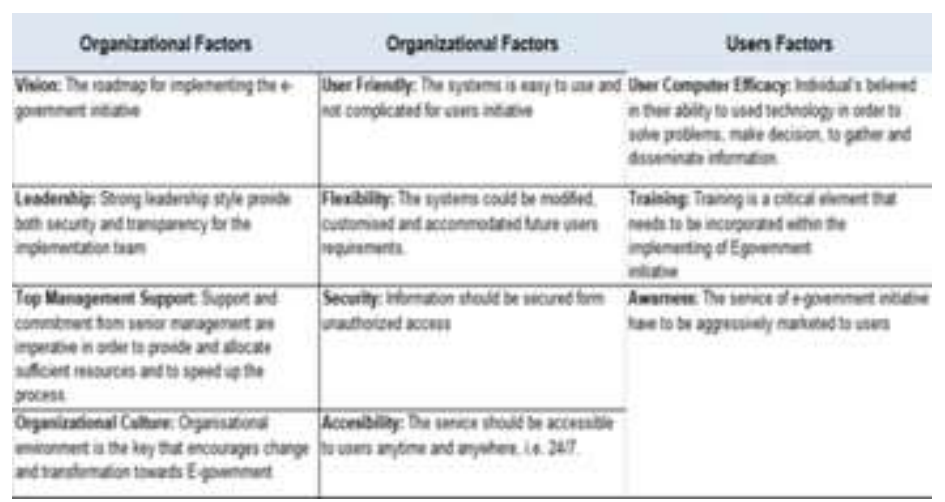

Fig. 3. The Development of Three Paradigms [12]

\subsection{E-Government Model Proposal}

In proposing this e-Government Village model, shown in figure 3, there are four models of e-Government development stages that can be used[14]. This model is divided into dimensions of technological complexity and organization with the level of data and information integration. The stages of development are: 
a. Cataloging, this stage focuses on how the government can provide various forms of information and present it to the website.

b. The transaction, a stage that has characteristics, there is an internal system in which the government is connected directly through the interface (GUI) and provides an opportunity for them to access it.

c. Vertical Integration, the stage which has the characteristic there is a relationship between the local and central government in one government administrative service functionality.

d. Horizontal Integration, a stage that has the characteristics of integration in cross functions and services

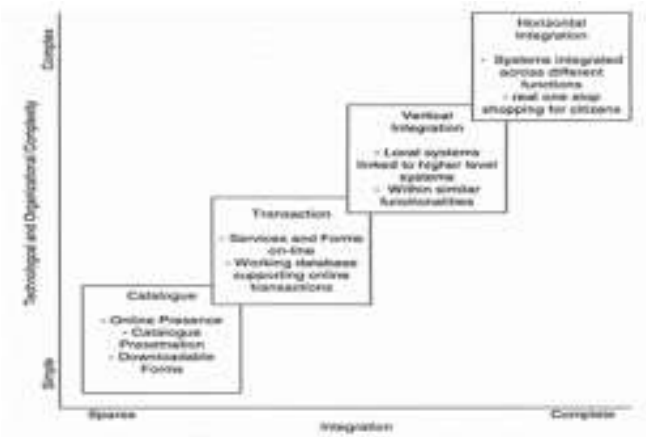

Fig. 4. e-Government Model[13]

\subsection{Future Development}

The future development process (portfolio future) will be more emphasized on the mapping of information and communication technology sourced from Mc Farlan Analysis, namely: strategic, high potential, key operational, and support shown in figure 5[11].

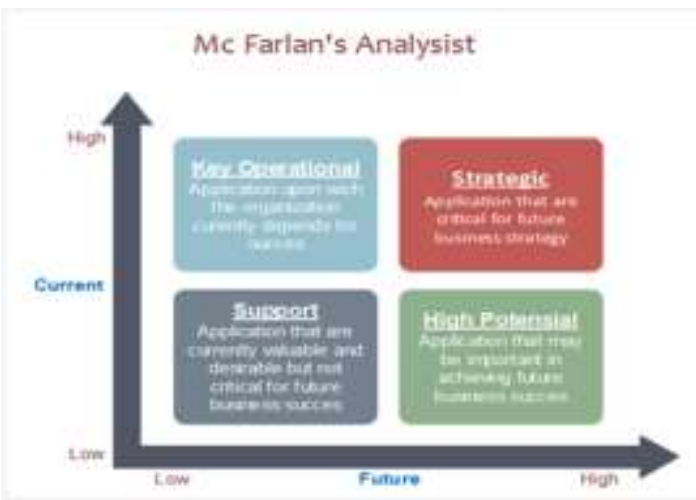

Fig.5 . Mc Farlan's Analysist 


\section{Results and Discussion}

\subsection{Analysis Results}

The results of the analysis were obtained from the identification process at the stage of one research method by interviewing and distributing questionnaires to identify the scope of the village. The basis for reference in conducting this analysis is Law Number 6 of 2014 concerning Village Arrangements[7]. At this stage, an analysis is based on the Critical Success Factor (CSF) to identify which areas are important targets in building e-Government Villages[[14].

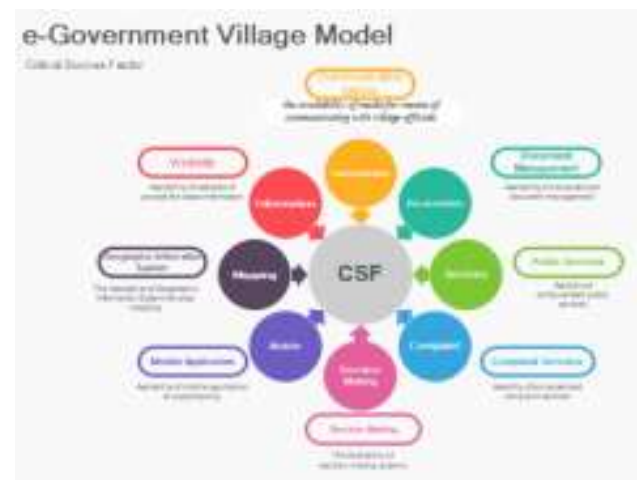

Fig. 6. Critical Succes Factor[14]

The results of the CSF analysis are to identify which points are the most critical and influential in the development of the e-Government Village model. The purpose of this CSF analysis is to interpret the objective more clearly to determine what activities should be carried out and what information is needed. Descriptions are more clearly in Table 1 below.

Table 1. CSF Village Overall

\begin{tabular}{lll}
\hline \multicolumn{1}{c}{ CSF } & \multicolumn{1}{c}{ Measurement } & \multicolumn{1}{c}{ ICT Needs } \\
\hline $\begin{array}{l}\text { The availability of media for } \\
\text { means of communicating with the } \\
\text { village officials }\end{array}$ & Accurate, fast, available 24 hours & Computer and internetwork \\
$\begin{array}{l}\text { The availability of computerized } \\
\text { document management }\end{array}$ & $\begin{array}{l}\text { Document search and management } \\
\text { is easier }\end{array}$ & $\begin{array}{l}\text { Information management } \\
\text { system for documents and } \\
\text { archives }\end{array}$ \\
$\begin{array}{l}\text { The Availability of computerized } \\
\text { public services }\end{array}$ & Easy, accurate, integrated, safe & $\begin{array}{l}\text { Administrative management } \\
\text { information system }\end{array}$ \\
$\begin{array}{l}\text { The availability of computerized } \\
\text { compliant services }\end{array}$ & Available 24 hours & $\begin{array}{l}\text { Mobile complaints portal } \\
\begin{array}{l}\text { The availability of decision- } \\
\text { making systems }\end{array}\end{array}$ \\
$\begin{array}{l}\text { The availability of a mobile } \\
\text { application }\end{array}$ & Accurate can be trusted & $\begin{array}{l}\text { Decision making an } \\
\text { information system }\end{array}$ \\
\hline
\end{tabular}




\begin{tabular}{lll}
\hline \multicolumn{1}{c}{ CSF } & \multicolumn{1}{c}{ Measurement } & \multicolumn{1}{c}{ ICT Needs } \\
\hline $\begin{array}{l}\text { The Availability of a computerized } \\
\text { village mapping system }\end{array}$ & Can be updated regularly & $\begin{array}{l}\text { Geographic Information } \\
\text { System }\end{array}$ \\
$\begin{array}{l}\text { The Availability of village } \\
\text { websites }\end{array}$ & Accurate, precise, fast & Village website \\
\hline
\end{tabular}

\subsection{E-Government Village Models proposal}

The results of the identification of the village scope and information technology used and the results of critical success factor analysis will produce a proposal for e-Government models such as Figure 6 below.

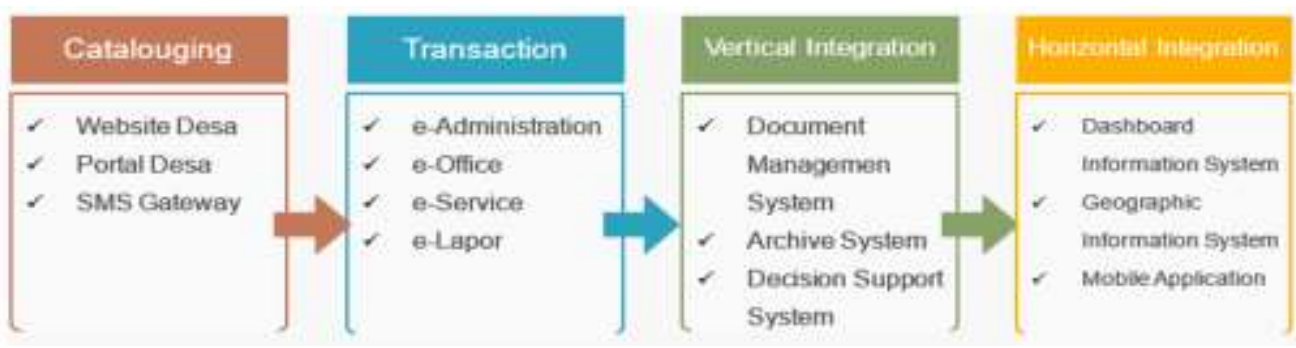

Fig. 7. e-Government Village Models propose

Whereas to follow 3 (three) patterns of implementation of Information Technology in eGovernment development, namely the relationship between government and society (G2C), government with the government $(\mathrm{G} 2 \mathrm{G})$, and government with business people (G2B), computer networks are needed as infrastructure[15]. The security and reliability aspects of communication must also be taken into account to ensure the confidentiality of population data and guarantee data availability and integrity[16]. Proposed computer networks and information security in the e-Government village model as shown in the following picture:

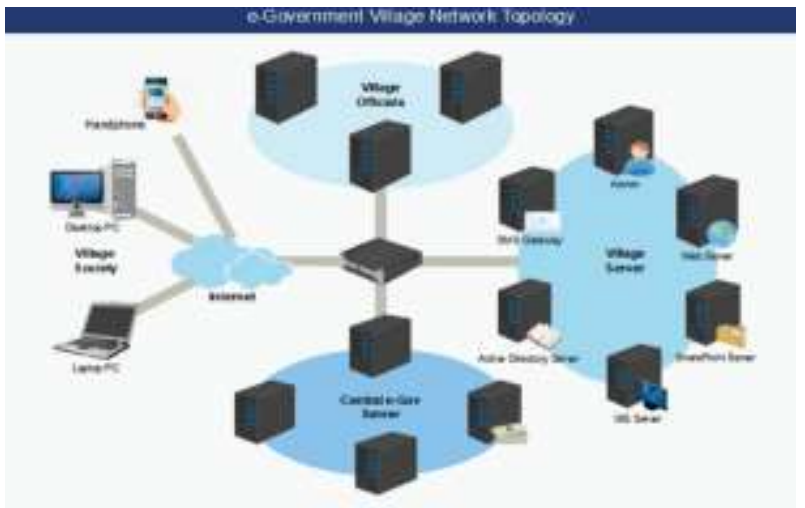

Fig. 8. e-Government Village Topology Proposal 


\subsection{Future Development (future portfolio)}

After obtaining identification on the scope of the village, conducting a study of information and communication technology used, and then mapping it into the proposed eGovernment model, the future portfolio is obtained by with McFarlan's Analyst Grid as shown in the following picture[17]:

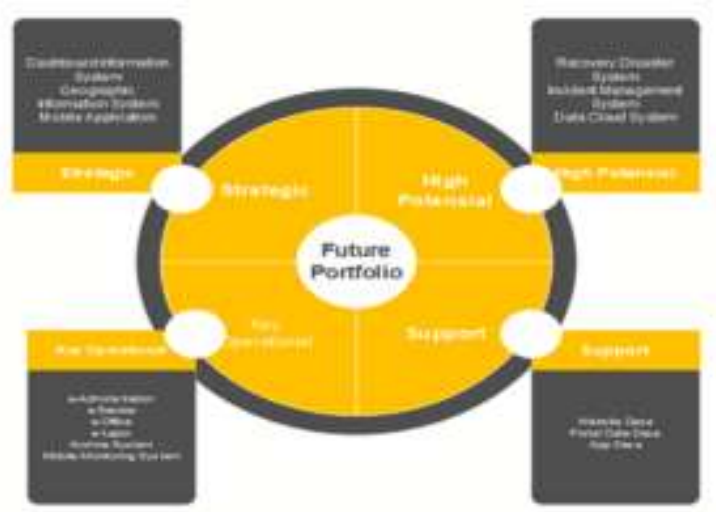

Fig. 9. Future Portfolio e-Government Desa

\subsection{Challenges of e-Government Villages}

E-Government provides optimal opportunities in providing services to the community. However, e-Government has challenges that must be considered, such as:

a. The technical issue, in-depth analysis of the selection of devices related to the amount of investment issued must be in line with the benefits obtained. This technical election must be appropriate by considering aspects of interoperability, privacy, security, and interaction with related parties.

b. Economical Issue, the development of an e-Government must pay attention to the costs incurred. This fee will be related to funds originating from community tax. This aspect will include costs, maintenance capabilities, reuse, and portability.

c. Social Issue, this issue is related to public acceptance of e-Government, such as aspects of access capability, ability to use, and acceptance of the new system.

\section{Conclusion}

After the analysis and results are obtained, this research can be summarized as follows:

a. The stages of identifying village scope are important in measuring village readiness using this e-Government model.

b. Future portfolios mapped into McFarlan's Analyst are proposed by e-Government models in this study.

c. Designing an information system dashboard is the most strategic element because it will help village officials to make decisions and assess historical village data.

d. Communication media based on mobile applications are worth considering in developing e-Government applications 


\section{References}

[1] D. Economic and Social Affairs, "United Nations e-Government Survey 2018," New York, 2018.

[2] S. Perdana and Y. E. Putra, "Model E-Government Pada Wilayah Administrasi Pemerintahan Tingkat Kelurahan,” J. Politek. Caltex Riau, vol. 2, no. 1, pp. 7-16, 2016.

[3] P. Republik Indonesia, Instruksi Presiden Republik Indonesia Nomor 3 Tahun 2003 Tentang Kebijakan Dan Strategi Nasional Pengembangan e-Government. Indonesia, 2003, pp. 53-65.

[4] P. Republik Indonesia, "Peraturan Presiden Republik Indonesia Nomor 95 Tahun 2018 Tentang Sistem Pemerintahan Berbasis Elektronik," Indonesia, pp. 1-110, 2018.

[5] I. D. GUCI, "Kata Menteri PANRB Soal Perpres E-Government," PORTALSATU, 2018. [Online]. Available: http://portalsatu.com/read/news/kata-menteri-panrb-soal-perpres-egovernment-39894. [Accessed: 05-Dec-2018].

[6] Y. Yudhanto, "E-government untuk Desa," Rumah Studio, 2016. [Online]. Available: http://rumahstudio.com/2016/10/29/e-government-untuk-desa/. [Accessed: 05-Dec-2018].

[7] P. Republik Indonesia, UU No.6 Tahun 2014 Tentang Desa, no. 1. 2014, p. 103.

[8] Yuniadi Mayowan, "PENERAPAN TEKNOLOGI INFORMASI DAN KOMUNIKASI DI DESA (Studi Kasus di Kabupaten Lamongan)," PROFIT J. Bus. Adm. FIA UB, vol. 10, no. 1, 2016.

[9] D. Bhatia, "Designing and Implementing e-Government Strategy," 2012.

[10] V. Kumar, B. Mukerji, I. Butt, and A. Persaud, "Factors for Successful e-Government Adoption : a Conceptual Framework," Electron. J. e-Government Vol., 2007.

[11] A. Ramadhan, D. I. Sensuse, Muladno, and A. M. Arymurthy, "Synthesizing success factors for e-government initiative," Res. J. Appl. Sci. Eng. Technol., vol. 6, no. 9, pp. 1685-1702, 2013.

[12] A. Al-Azri, Z. Al-Salti, and W. Al-Karaghouli, "The successful implementation of egovernment transformation: A case study in Oman," Eur. Mediterr. Middle East. Conf. Inf. Syst. 2010, vol. 2010, pp. 1-11, 2010.

[13] O. Signore, I. National, and F. Chesi, "E-Government: Challenges and Opportunities," in CMG Italy, XIX Annual Conference, 2005, no. June 2005.

[14] D. Napitupulu, "The Critical Success Factors Study for e-Government Implementation," Int. J. Comput. Appl., vol. 89, no. 16, pp. 23-32, Mar. 2014.

[15] W. Fajrillah, Zarina, "Smart city vs smart village," J. Mantik Penusa, vol. 22, no. 1, pp. 1-6, 2018.

[16] R. Watrianthos and M. Nasution, "Analisa Kemampuan Transfer Data VPN Berbasis Open Source Pada Kondisi Enkripsi-Dekripsi dan Kompresi-Dekompresi," Inform. AMIK Labuhan Batu, vol. Vol.6 No.1, no. 1, 2018.

[17] K. Hardjanto, "Strategic Planning of Information Systems at Departement of Agriculture, Animal Husbandry and Fisheries Magelang With Ward and Peppard Framework," J. Teknol. Inf. dan Komun., vol. 4, no. 2, pp. 88-99, 2015. 